\title{
Influence of dietary supplementation of carotenoid (diacetate of lutein-mesozeaxanthin) on growth performance, biochemical body composition in freshwater prawn, macrobrachium rosenbrgii
}

\begin{abstract}
The aim of this study was to evaluate effects of one of the carotenoids (diacetate of luteinmesozeaxanthin) on growth performance, proximate composition of body and water quality in freshwater prawn, M. rosenbergiiin fiber reinforced plastic tanks (120 1 capacity) for 60 days in a recirculatory aquaculture system. Uniform sized PL of M. rosenbergiiwith an average range of weight ( 0.32 to $0.37 \mathrm{~g}$ ) was used for the study. The study was carried out in triplicate groups and prawns were stocked at the rate of 50 numbers per tank. Three test diets namely $\mathrm{T}_{1}, \mathrm{~T}_{2}$ and $\mathrm{T}_{3}$ with $35 \%$ protein content were formulated. Diet $\mathrm{T}_{1}$ had $60 \mathrm{ppm}, \mathrm{T}_{1}$ had $120 \mathrm{ppm}$ and $\mathrm{T}_{3}$ had $180 \mathrm{ppm}$ Diacetate of lutein-mesozeaxanthin and diet without diacetate of lutein-mesozeaxanthin supplementation served as control $\left(\mathrm{T}_{0}\right)$. Growth parameters and survival factors were analyzed at the end of feeding trial. After 60 days, weight gain $(1.238 \pm 0.07)$, Specific Growth Rate (2.53 \pm 0.05$)$, Feed Efficiency Rate $(0.440 \pm 0.00)$, Protein Efficiency Rate $(1.259 \pm 0.00)$, Survival Rate $(80.00 \pm 12.02)$, Percentage of Mean Weight Gain (356.77 \pm 0.65$)$, Daily Growth Rate (5.94 \pm 0.21$)$, Daily Growth Index $(0.77 \pm 0.08)$, Growth Coefficient $(1.630 \pm 0.05)$ were higher in prawns fed the Diacetate of lutein-mesozeaxanthin added diets compared to control and lower feed conversion ratio (2.26 \pm 0.01$)$ was observed in $\mathrm{T}_{3}$. The best results of $M$. rosenbergiiin terms of growth factors were recorded in treatment $\mathrm{T}_{3}$ followed by $\mathrm{T}_{2}, \mathrm{~T}_{1}, \mathrm{~T}_{0}$, and significant differences $(\mathrm{P}<0.01)$ were observed among treatments according to growth parameters, but there was no significant difference $(\mathrm{P}>0.05)$ between them with regard to survival rate. There were no significant differences in water quality and proximate composition among different treatments. These findings demonstrated the dietary carotenoid (diacetate of lutein-mesozeaxanthin) can be used for enhancing of growth in M. rosenbergii, but no effect on survival, water quality and proximate composition.
\end{abstract}

Keywords: Carotenoid (Diacetate of lutein-mesozeaxanthin), Growth performance, Biochemical composition, M. rosenbergii
Volume 4 Issue 2 - 2016

\author{
Shivananda Murthy,' Hosseinpoor Zelaty,' \\ Majid Nazarkardeh, ${ }^{2}$ Seyyedeh Hoda \\ Ahmadiyan, ${ }^{3}$ Meshram SJ,' Adnan Amin,' \\ Swain HS' \\ 'Department of Aquaculture, College of Fisheries (KVAFSU), \\ India \\ ${ }^{2}$ Faculty of Range land and Watershed Management, Gorgan \\ University of Agricultural Sciences \& Natural Resources, Iran \\ ${ }^{3}$ Department of Biology, Islamic Azad University, Iran
}

Correspondence: Shivananda Murthy, Department of Aquaculture, College of Fisheries (KVAFSU) and Mangalore 575 002, Karnataka, India, Email hsmurthy05@yahoo.com

Received: October 23, 2015 | Published: March 31, 2016

\section{Introduction}

Macrobrachium rosenbergii ${ }^{1}$ the most commercially cultured palaemonid in the world. Because of its fast growth, large size, moderate disease tolerance and export market value, the species has been widely used in aquaculture and has thus been introduced throughout the tropical and temperate regions of the world. It is now cultured at least in 43 countries across five continents, with Asia contributing more than $98 \%$ of global production. ${ }^{2}$ Global production of this prawn exceeded 200000 metric tons (mt) in $2008^{3}$ with potential scope for growth. In Asia, the major producers are China, India, Viet Nam, Thailand and Bangladesh. In India too, a spurt in freshwater prawn farming has been seen in recent years. Considering its high export market, the giant freshwater prawn enjoys immense potential for culture in India. Demand for this species in both domestic and international markets are increasing, hence programming and planning for increase in production of $M$. rosenbergii is necessary. Use of carotenoids can influence growth and survival of fish and shellfishes, but the effects of carotenoids on growth and survival of aquatic organisms have been controversial, because several studies reporting a positive influence on growth, whereas others did not find any effect. ${ }^{4}$ The Diacetate of lutein-mesozeaxanthin is a paste like compound, it contains the acetylated forms of lutein and meso-zeaxanthin which is one of the Carotenoids and can be used for different purposes in aquatic animals as well as crustaceans especially in prawn culture. However, it was not used as a feed additive for growth purpose so far and this study was done for first time. But similar carotenoids were used for different objectives in aquaculture production such as fish and shellfish culture. Pre-juvenile $(0.115 \mathrm{~g})$ white shrimp (L. Vannamei) fed dietary supplementation of Hi-Zeaxanthin or Zeaxanthin short chain like diactate during 7 weeks, the average weight and survival rate was significantly higher than control group. ${ }^{5}$ White shrimp (L. Vannamei) were fed with three different treatments (synthetic astaxanthin, lutein and astananthin derives from marigold extract), results have shown higher growth, lower FCR and higher survival on marigold treatments as compared to other treatments and control group $^{6,7}$ reported a higher survival rate and growth in P. Japanicus fed with astaxathin-supplemented diets than that of $\beta$-carotene or algal meal ${ }^{8}$ have studied that the Atlantic Salmon fed with two xanthophylls carotenoids (astaxanthin and lutein), had no significant effect on growth performance such as FCR, SGR, WG and condition factor. Eduardo et al. ${ }^{9}$ have noted that supplementation of experimental diets with (Tagetes erecta) extract (marigold oleoresin) on L. vannamei did not significantly alter the proximate composition of the practical 
diet because very small amounts were required to attain the desired concentrations in the feeds (less than $0.5 \%$ of the total ingredients). The same results were reported by Arredondon \& Flores et al. ${ }^{10,11}$ This study was conducted to determine whether diacetate of luteinmesozeaxanthin would affect on growth performance, biochemical composition and water quality in freshwater prawn, M. rosenbrgii. Carotenoids are pigments naturally occurring in a number of fruits and vegetables. They are synthesized by all photosynthetic organisms and many non-photosynthetic bacteria and fungi. There are two main classes of naturally occurring carotenoids: (1) carotenes such as $\beta$-carotene and $\alpha$-carotene, which are hydrocarbons, are either linear or cyclized at one or both ends of the molecule, and (2) xanthophylls, the oxygenated derivatives of carotenes. All xanthophylls produced by higher plants, such as violaxanthin, antheraxanthin, zeaxanthin, neoxanthin, and lutein, are also synthesized by green algae. ${ }^{12}$ Xanthophylls (oxygenated carotenoids) are used as additives for poultry (e.g. chicken), crustaceous (e.g. shrimp) and fish (e.g. salmon) feeds to provide bright colours in egg yolks, skin, and fatty tissues due to its pigmenting properties. ${ }^{13-16}$ Among the xanthophylls, lutein, and zeaxanthin are two of the most abundant oxygenated carotenoids found in the diet. ${ }^{17}$ Chemically, lutein and zeaxanthin (Figure 1) contain two cyclic end groups ( $\alpha, \beta$ and and $\alpha$-ionone ring) and the basic $\mathrm{C}_{40}$ isoprenoid structure common to all carotenoids. Structurally, lutein and zeaxanthin have identical chemical formulas and are isomers, but they are not stereoisomers. The chemical formula of lutein and zeaxanthin is $\mathrm{C}_{4} 0 \mathrm{H}_{56} \mathrm{O}_{2}$ and the molecular weight is 568.88 . The main difference between them is in the location of a double bond in one of the end rings (Figure 1).$^{18}$ Reported that the minute structural differences are responsible for variations in the biological activities of these compounds (carotenoids). ${ }^{19}$ Indicated that multiple conjugate double bonds exist in carotenoids, which confer specific biological characteristics on the family of carotenoids. Furthermore, the orientation of carotenoids depends on the molecular structure. While lutein is present as a single stereoisomer, zeaxanthin occurs as a mixture of three isomers, ${ }^{20}$ two of which are referred to as zeaxanthin and meso-zeaxanthin, respectively. ${ }^{21}$ Meso-zeaxanthin is a unique member of the xanthophylls family of carotenoids and along with lutein $[(3 \mathrm{R}, 30 \mathrm{R}, 60 \mathrm{R})-\mathrm{b}$, e-carotene-3, 30-diol)] (L) and zeaxanthin [(3R,30R)-b,b-carotene-3.30diol] $(\mathrm{Z})$ are members of the xanthophylls class of carotenoids..$^{22-24}$ The presence of mesozeaxanthin was reported in shrimp carapace, fish skin, and turtle fat, where all three isomers of zeaxanthin were found. ${ }^{25}$ The Diacetate of lutein-mesozeaxanthin is a paste like compound. It contains the acetylated forms of lutein and meso-zeaxanthin. Diacetate, a salt or ester containing two acetate groups $\left(\mathrm{CH}_{3} \mathrm{COO}-+\mathrm{CH}_{3} \mathrm{COO}-\right)$, whereas acetate, a salt or ester of acetic acid $(\mathrm{CH} 3 \mathrm{COOH})$, on the other hand, acetate are usually seen derivatives of acetic acid and acetate is also the ion formed when acetic acid losses it acidic hydrogen: $\mathrm{CH}_{3} \mathrm{COOH}$---------- $\mathrm{H}++\mathrm{CH}_{3} \mathrm{COO}$.

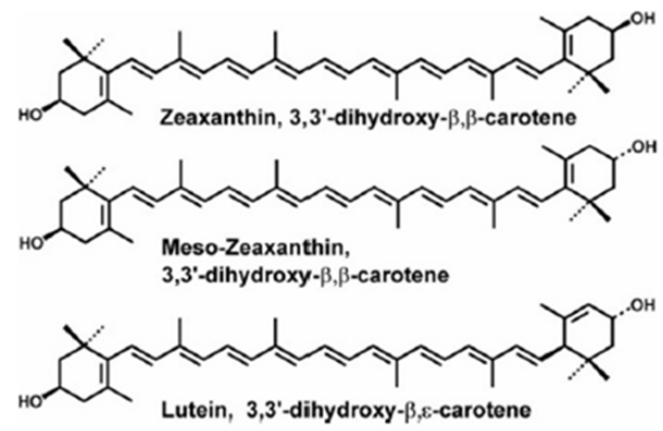

Figure I Chemical structure of lutein, zeaxanthin and meso-zeaxanthin.

\section{Materials and methods}

\section{Carotenoids (Diacetate of lutein-mesozeaxanthin)}

The study was conducted in fiber reinforced plastic tanks (120 1 capacity) in indoor recirculatory system at the fish farm of the College of Fisheries, Mangalore to evaluate the effect of diacetate of luteinmesozeaxanthin on growth factors, proximate composition of protein and water quality in rearing M. rosenbergii. The study was carried out in triplicate tanks for each treatment for a period of 60 days. The complete randomized design (CRD) was followed.

\section{Proximate composition of the feed ingredients}

All the feed ingredients were analyzed for proximate composition prior to formulation of the test diets employing standard methods (AOAC, 1975). Moisture content was estimated by heating samples at $105^{\circ} \mathrm{C}$ for $30 \mathrm{~min}$ and then cooling and weighing to a constant weight. Crude protein was analyzed using Kjeltec system (Tecater 1002 Distilling Unit), fat content by Soxtech System (Tecater 1043 Extraction Unit), and fibre content by using Fibretech System (Tecater 1017 Hot Extractor). Carbohydrate content was calculated as nitrogen free extract (NFE) by the difference method as given below.

NFE $=100-(\%$ moisture $+\%$ crude protein $+\%$ crude fat $+\%$ crude fibre $+\%$ ash)

The ash content was determined by first drying the sample and then heating it in a muffle furnace at $550 \pm 10^{\circ} \mathrm{C}$ for $6 \mathrm{~h}$. The proximate composition of the ingredient used in the experimental diets and proximate composition of experimental diets are given in Tables 1 $\& 2$.

\section{Diet preparation}

The ingredients used in the formulation of different experimental diets were fishmeal, rice bran, groundnut oil cake, wheat flour, soya beans meal, shrimp meal and vitamin and mineral premix. The basal diet was supplemented with diacetate of lutein-mesozeaxanthin, ground and sieved to get particles of uniform size. Three test diets namely $\mathrm{T}_{1}, \mathrm{~T}_{2}$ and $\mathrm{T}_{3}$ having $35 \%$ protein were formulated using the square method. ${ }^{26}$ Diet $\mathrm{T}_{1}$ had $60 \mathrm{mg} / \mathrm{kg}$ diacetate of luteinmesozeaxanthin, $\mathrm{T}_{2}$ had $120 \mathrm{mg} / \mathrm{kg}$ diacetate of lutein-mesozeaxanthin and $\mathrm{T}_{3}$ had $180 \mathrm{mg} / \mathrm{kg}$ diacetate of lutein-mesozeaxanthin, and the diet without diacetate of lutein-mesozeaxanthin supplementation served as a control $\left(\mathrm{T}_{0}\right)$. The required quantities of ingredients were weighed accurately, mixed and hand needed to required consistency with just sufficient quantity of water (1:0.8) to get smooth dough. The dough so obtained was cooked under steam in a pressure cooker at $105^{\circ} \mathrm{C}$ for 20 to $30 \mathrm{~min}$. The cooked feed was cooled to room temperature rapidly by spreading in an enamel tray. Then required dose of marigold oleoresin and vitamin-mineral premix were added, mixed and blended. The dough was extruded through a pelletize. Pellets of size $1.2 \mathrm{~mm}$ were dried in a hot air oven at $60^{\circ} \mathrm{C}$ till the moisture content was reduced to less than $10 \%$. Diets were packed separately in high density polythene bags, labelled and stored in a wooden shelf at room temperature for further use.

\section{Diet preparation}

The ingredients used in the formulation of different experimental diets were fishmeal, rice bran, groundnut oil cake, wheat flour, soya beans meal, shrimp meal and vitamin and mineral premix. The basal diet was supplemented with diacetate of lutein-mesozeaxanthin, ground and sieved to get particles of uniform size. Three test diets namely $\mathrm{T}_{1}, \mathrm{~T}_{2}$ and $\mathrm{T}_{3}$ having $35 \%$ protein were formulated using 
the square method. ${ }^{26}$ Diet $\mathrm{T}_{1}$ had $60 \mathrm{mg} / \mathrm{kg}$ diacetate of luteinmesozeaxanthin, $\mathrm{T}_{2}$ had $120 \mathrm{mg} / \mathrm{kg}$ diacetate of lutein-mesozeaxanthin and $\mathrm{T}_{3}$ had $180 \mathrm{mg} / \mathrm{kg}$ diacetate of lutein-mesozeaxanthin, and the diet without diacetate of lutein-mesozeaxanthin supplementation served as a control $\left(\mathrm{T}_{0}\right)$. The required quantities of ingredients were weighed accurately, mixed and hand needed to required consistency with just sufficient quantity of water (1:0.8) to get smooth dough. The dough so obtained was cooked under steam in a pressure cooker at $105^{\circ} \mathrm{C}$ for 20 to $30 \mathrm{~min}$. The cooked feed was cooled to room temperature rapidly by spreading in an enamel tray. Then required dose of marigold oleoresin and vitamin-mineral premix were added, mixed and blended. The dough was extruded through a pelletize. Pellets of size $1.2 \mathrm{~mm}$ were dried in a hot air oven at $60^{\circ} \mathrm{C}$ till the moisture content was reduced to less than $10 \%$. Diets were packed separately in high density polythene bags, labelled and stored in a wooden shelf at room temperature for further use.

Table I Proximate composition of the ingredient (\% on dry weight basis) used in the experimental diets

\begin{tabular}{llllllll}
\hline Ingredients & Dry matter (\%) & Crude protein (\%) & Crude fat (\%) & Crude fibre (\%) & Ash (\%) & NFE (\%) & Energy Kcal /Kg \\
\hline Fish meal & 94.86 & 62.28 & 9.53 & 0.72 & 18.82 & 3.51 & 4523.90 \\
Rice bran & 93.17 & 6.90 & 4.98 & 28.62 & 15.60 & 37.07 & 2337.32 \\
Shrimp meal & 91.89 & 62.07 & 3.08 & 1.69 & 17.10 & 7.95 & 4082.44 \\
Groundnut oilcake & 92.99 & 34.28 & 6.89 & 3.02 & 10.80 & 38.00 & 4087.34 \\
Wheat flour & 93.50 & 11.23 & 1.73 & 1.42 & 1.28 & 77.84 & 3905.10 \\
Soya flour & 91.66 & 39.67 & 19.62 & 6.50 & 5.24 & 20.63 & 4891.00
\end{tabular}

Table 2 Proximate composition of experimental diets (\% on dry weight basis)

\begin{tabular}{|c|c|c|c|c|}
\hline \multirow{3}{*}{$\begin{array}{l}\text { Parameters } \\
\text { Dry matter (\%) }\end{array}$} & \multicolumn{4}{|c|}{ Dietary treatments } \\
\hline & \multirow{2}{*}{$\begin{array}{l}\text { Control } \\
93.50\end{array}$} & \multirow{2}{*}{$\begin{array}{l}60 \mathrm{mg} / \mathrm{kg} \\
92.76\end{array}$} & \multicolumn{2}{|c|}{ | 20 mg/kg | 80 mg/kg } \\
\hline & & & 93.15 & 92.85 \\
\hline Crude protein (\%) & 35.09 & 34.95 & 35.20 & 34.87 \\
\hline Crude fat (\%) & 7.52 & 7.65 & 7.40 & 7.76 \\
\hline Crude fibre (\%) & 26.28 & 27.05 & 26.15 & 27.45 \\
\hline Ash (\%) & 15.05 & 16.10 & 15.70 & 15.65 \\
\hline NFE (\%) & 9.56 & 7.01 & 8.70 & 6.12 \\
\hline Energy Kcal / Kg & 3054.32 & 2956.70 & 3014.80 & 2926.96 \\
\hline
\end{tabular}

*Means of three replicates.

\section{Experimental animals, stocking and feeding}

The post larvae (PL-20) produced in the Prawn Hatchery at the College of Fisheries, Mangalore was reared in cement tanks and juveniles were used for experiments. The juveniles were acclimatized to the experimental condition by feeding with dry pelleted basal diet. Uniform sized PL of $M$. rosenbergiiwith an average range of weight ( 0.85 to $0.89 \mathrm{~g})$ was stocked at the rate of 50 numbers per tank. The experiment was carried out for a period of 60 days with an exchange of water once in two days in the tank. Fecal matter and uneaten food was removed daily in the morning hours. Prawns were fed at the rate of $5 \%$ of their body weight till the end of the experiment. The feed was broadcasted over the surface of water twice daily in the morning and evening. After each sampling the quantity of feed given was readjusted based on the increased weight of prawn.

\section{Water quality}

Water samples were collected for determining its quality every fortnight. Water quality parameters were maintained within the normal range throughout the experimental period. Water samples collected on each sampling day were analyzed for $\mathrm{pH}$, temperature, dissolved oxygen, free carbon dioxide, $\mathrm{NH}_{3}-\mathrm{N}$ and total alkalinity. Digital pocket $\mathrm{pH}$ meter (Hanna) was used to record $\mathrm{pH}$. Atmospheric temperature and water temperature were recorded by using thermometer. Dissolved oxygen was estimated by Winkler's method. Total alkalinity, $\mathrm{NH}_{3}$ and free carbon dioxide were determined by following standard methods. ${ }^{27}$

\section{Prawn sampling}

The prawns were sampled every fortnight to assess the growth Length was measured from tip of rostrum to tip of telson by using a fibreglass measuring scale fixed on wooden frame. Weight was measured on electronic balance (Essae, India).

\section{Biochemical composition}

Proximate composition of prawn muscle was estimated soon after completion of the experiment. All the prawns were peeled and deveined. Whole meat of the prawn was dried at $60^{\circ} \mathrm{C}$ for $48 \mathrm{hrs}$ to obtain the dry matter. The dry matter was powdered in mortar and used for further analysis. The samples were analyzed for crude protein, crude fat, total ash and carbohydrate (NFE) employing standard methods as explained earlier.

\section{Statistical analysis}

Mean growth of prawn achieved in response to different formulated test diets were estimated statistically by using one way analysis of variance (ANOVA) followed by Duncan's multiple range test were done by using SPSS software (16.0 version).

\section{Results}

\section{Water quality parameters}

The results of water quality parameters such as temperature, $\mathrm{pH}$, dissolved oxygen, free carbon dioxide, total alkalinity and ammonianitrogen are presented in Table 3. Temperature of water ranged from $28.5^{\circ} \mathrm{C}$ to $29.5^{\circ} \mathrm{C}$ and mean value of water temperature had not significantly fluctuated during experiment. The $\mathrm{pH}$ recorded during the study period, ranged from 7.8 to 9.1 but mean value of $\mathrm{pH}$ water did not vary significantly in duration of feeding trial. The average values of dissolved oxygen were $7.77 \pm 0.24$ to $7.89 \pm 0.18$ in different treatments and did not find significantly difference among them, as 
well as other parameters of water quality namely; free carbon dioxide, total alkalinity and total ammonia-nitrogen were in normal range and significant differences among treatment groups and control was not observed.

\section{Growth studies}

The increase in weight of prawn in treatments and control during experimental period are given in Table 4. It was observed that the best growth of prawn, $M$. rosenbergiiin terms of weight was recorded in treatment $\mathrm{T}_{3}$ followed by the treatment $\mathrm{T}_{2}, \mathrm{~T}_{1}$ and $\mathrm{T}_{0}$. The average

Table 3 Water quality parameters recorded in different experimental tanks final weight recorded after 60 days of culture in treatment $\mathrm{T}_{3}$ was $1.585 \pm 0.08 \mathrm{~g}$, followed by $1.518 \pm 0.05 \mathrm{~g}$ in $\mathrm{T}_{2}, 1.420 \pm 0.08 \mathrm{~g}$ in $\mathrm{T}_{1}$ and $1.225 \pm 0.07 \mathrm{~g}$ in $\mathrm{T}_{0}$. Specific Growth Rate (\%/ day) of prawn was highest in $\mathrm{T}_{3}(2.53 \pm 0.05)$, followed by $\mathrm{T}_{2}(2.45 \pm 0.12), \mathrm{T}_{1}(2.39 \pm .06)$ and $\mathrm{T}_{0}(2.09 \pm 0.07)$. The best results of WG (1.238 \pm 0.07$)$, PER $(1.259 \pm 0.00), \quad$ FCR $\quad(2.26 \pm 0.01), \quad$ SR $\quad(80.00 \pm 12.02 \%), \quad$ FER $(0.440 \pm 0.00)$, PDG $(0.020 \pm 0.06 \mathrm{~g})$, PMVG $(356.77 \pm 0.65 \%)$, DGR $(5.94 \pm 0.21)$, DGI $(0.77 \pm 0.08)$ and $\mathrm{GC}(2.543 \%)$ was obtained in $\mathrm{T}_{3}$ followed by $\mathrm{T}_{2}, \mathrm{~T}_{1}$.

\begin{tabular}{|c|c|c|c|c|}
\hline \multirow{2}{*}{ Water parameter } & \multicolumn{4}{|c|}{ Dietary treatments } \\
\hline & Control & $60 \mathrm{mg} / \mathrm{kg}$ & $120 \mathrm{mg} / \mathrm{kg}$ & $180 \mathrm{mg} / \mathrm{kg}$ \\
\hline W.T'. & $29.18 \pm 0.18$ & $29.22 \pm 0.17$ & $29.10 \pm 0.14$ & $29.25 \pm 0.15$ \\
\hline $\mathrm{pH}$ & $8.56 \pm 0.11$ & $8.56 \pm 0.11$ & $8.5 I \pm 0.11$ & $8.44 \pm 0.13$ \\
\hline D. $\mathrm{O}^{2}$ & $7.83 \pm 0.19$ & $7.77 \pm 0.24$ & $7.89 \pm 0.18$ & $7.85 \pm 0.19$ \\
\hline F.C.D $D^{3}$ & $0.83 \pm 0.11$ & $0.78 \pm 0.09$ & $0.85 \pm 0.07$ & $0.90 \pm 0.10$ \\
\hline T. $\mathrm{A}^{4}$ & $78.19 \pm 1.69$ & $78.05 \pm 1.44$ & $77.66 \pm 1.65$ & $77.87 \pm 1.51$ \\
\hline T.A. $N^{5}$ & $0.04 \pm 0.01$ & $0.04 \pm 0.00$ & $0.04 \pm 0.01$ & $0.04 \pm 0.00$ \\
\hline
\end{tabular}

I.Water temperature

2. Dissolved oxygen

3. Free carbon dioxide

4. Total alkalinity

5. Total ammonia-nitrogen.

Table 4 Growth parameters of M. rosenbergiifed with different marigold oleoresin levels

\begin{tabular}{|c|c|c|c|c|}
\hline \multirow{2}{*}{ Growth Indices } & \multicolumn{4}{|c|}{ Dietary Treatments } \\
\hline & Control & $T_{1}(60 \mathrm{mg} / \mathrm{kg})$ & $T_{2}(120 \mathrm{mg} / \mathrm{kg})$ & $\mathrm{T}_{3}(180 \mathrm{mg} / \mathrm{kg})$ \\
\hline Initial weight (g) & $0.348 \pm 0.00$ & $0.347 \pm 0.00$ & $0.348 \pm 0.00$ & $0.347 \pm 0.00$ \\
\hline Final weight $(g)$ & $1.225 \pm 0.07$ & $1.420 \pm 0.08$ & $1.518 \pm 0.05$ & $1.585 \pm 0.08$ \\
\hline Mean Weight Gain (g) & $0.877 \pm 0.06^{\mathrm{a}}$ & $1.073 \pm 0.07^{\mathrm{ab}}$ & $1.170 \pm 0.07^{\mathrm{b}}$ & $1.238 \pm 0.07^{b}$ \\
\hline Specific Growth Rate (\%) & $2.09 \pm 0.07^{a}$ & $2.39 \pm .06^{\mathrm{ab}}$ & $2.45 \pm 0.12^{\mathrm{b}}$ & $2.53 \pm 0.05^{b}$ \\
\hline Feed Conversion Ratio & $2.73 \pm 0.16^{\mathrm{a}}$ & $2.46 \pm 0.14^{\mathrm{a}}$ & $2.32 \pm 0.16^{\mathrm{a}}$ & $2.26 \pm 0.0 \mathrm{I}^{\mathrm{a}}$ \\
\hline Protein Efficiency Rate & $1.043 \pm 0.05^{\mathrm{a}}$ & $1.159 \pm 0.06^{\mathrm{a}}$ & $1.226 \pm 0.08^{\mathrm{a}}$ & $1.259 \pm 0.00^{\mathrm{a}}$ \\
\hline Survival Rate (\%) & $69.32^{\mathrm{a}}$ & $74.00^{\mathrm{a}}$ & $77.32^{\mathrm{a}}$ & $80.00^{\mathrm{a}}$ \\
\hline Feed Efficiency Rate & $0.365 \pm 0.02^{\mathrm{a}}$ & $0.405 \pm 0.02^{\mathrm{a}}$ & $0.429 \pm 0.02^{\mathrm{a}}$ & $0.440 \pm 0.00^{\mathrm{a}}$ \\
\hline Per Day Growth(g) & $0.0146^{a}$ & $0.0178^{\mathrm{ab}}$ & $0.0195^{b}$ & $0.020^{\mathrm{b}}$ \\
\hline Percentage of Mean Weight Gain (\%) & $252.0 \mathrm{I}^{\mathrm{a}}$ & $309.22^{\mathrm{ab}}$ & $336.2^{\mathrm{ab}}$ & $356.77^{\mathrm{b}}$ \\
\hline Condition Factor & $\left.1.9\right|^{\mathrm{a}}$ & $2.07^{a}$ & $1.94^{\mathrm{a}}$ & $1.78^{\mathrm{a}}$ \\
\hline Daily Growth Rate (g) & $4.20^{\mathrm{a}}$ & $5.15^{\mathrm{ab}}$ & $5.60^{\mathrm{b}}$ & $5.94^{\mathrm{b}}$ \\
\hline Daily Growth Index & $0.6 \mathrm{I}^{\mathrm{a}}$ & $0.70^{\mathrm{ab}}$ & $0.74^{b}$ & $0.77^{\mathrm{b}}$ \\
\hline Growth Coefficient (\%) & $1.288^{\mathrm{a}}$ & $1.482^{\mathrm{ab}}$ & $1.570^{\mathrm{b}}$ & $1.630^{\mathrm{b}}$ \\
\hline
\end{tabular}

Growth analysis: The growth parameters were calculated by using the following formula:

- Mean weight gain $(\mathrm{g})=\mathrm{Wf}(\mathrm{g})-\mathrm{Wi}(\mathrm{g})^{28}$

- Feed Conversion Rate $(\mathrm{FCR})=$ total feed consumed $(\mathrm{g}) /$ (initial number of fishes/final number of fishes ${ }^{29}$

-Per day growth $(\mathrm{g})=$ mean weight gain $(\mathrm{g}) /$ number of days ${ }^{28}$

-Survival $(\%)=$ number of fishes survival at the end of the experiment/number of fishes stocked at the start of the experiment ${ }^{30}$

-Percentage of mean weight gain $(\mathrm{PMWG})=((\mathrm{Wf}(\mathrm{g})-\mathrm{Wi}(\mathrm{g})) / \mathrm{Wi}$ $(\mathrm{g}) \times 100^{31}$

- Specific growth rate $(\mathrm{SGR})=\{(\mathrm{Ln} \mathrm{Wf}(\mathrm{g})-\mathrm{Ln} \mathrm{Wi}(\mathrm{g})) / \mathrm{t}\}$

-Condition factor $(\mathrm{CF})=\mathrm{W} \times 100 / \mathrm{L}^{30}$
-Daily growth rate $(\mathrm{DGR})=\{100 \times($ final weight $(\mathrm{g})$-initial weight $(\mathrm{g}) /($ days $\times$ initial weight $(\mathrm{g})))^{29}$

-Daily growth index $(\mathrm{DGI})=\{100 \times(\mathrm{Wf1} / 3-\mathrm{Wi1} / 3) / \text { days }\}^{29}$

-Growth coefficient $(\mathrm{GC})=\{100 \times(\mathrm{Wf1} / 3-\mathrm{Wi1} / 3) / \Sigma \theta\},{ }^{29}$ where $\mathrm{Wf}=$ Final weight, $\mathrm{Wi}=$ Initial weight, $\Sigma \theta=$ sum of average daily temperature in ${ }^{\circ} \mathrm{C}$

\section{Biochemical composition}

The results of biochemical composition of prawn muscle recorded at the end of the experiment are shown in Table 5. Maximum moisture content was recorded in $\mathrm{T}_{0}(80.86 \pm 0.56 \%)$ and minimum in $\mathrm{T}_{3}(78.46 \pm 0.54 \%)$. The values were $78.59 \pm 0.42 \%$ in $\mathrm{T}_{1}$ and $78.80 \pm 0.49 \%$ in $\mathrm{T}_{2}$. Protein content of prawn muscle was maximum in $\mathrm{T}_{2}(22.95 \pm 0.27 \%)$ followed by $\mathrm{T}_{0}(21.80 \pm 0.24 \%), \mathrm{T}_{1}(22.73 \pm 0.18$ $\%$ ) and $\mathrm{T}_{3}(22.42 \pm 0.16 \%)$. Crude fat was maximum in $\mathrm{T}_{0}(1.8 \pm 0.11 \%)$ 
and minimum in $\mathrm{T}_{3}(1.3 \pm 0.15 \%)$. Intermediate values of $1.7 \pm 0.20$ $\%$ in $\mathrm{T}_{2}$ and $1.5 \pm 0.19 \%$ in $\mathrm{T}_{1}$. Ash levels were $5.8 \pm 0.21 \%$ in $\mathrm{T}_{2}$, $5.3 \pm 0.18 \%$ in $\mathrm{T}_{0}, 5.2 \pm 0.17 \%$ in $\mathrm{T} 3$ and $4.9 \pm 0.13 \%$ in $\mathrm{T}_{1}$. The highest NFE was recorded in $\mathrm{T}_{1}(1.6 \pm 0.09 \%)$, followed by $\mathrm{T}_{2}(1.5 \pm 0.08 \%)$,
$\mathrm{T}_{3}(1.4 \pm 0.04 \%)$ and $\mathrm{T}_{0}(1.3 \pm 0.06 \%)$. On the basis of these results there were no significant differences among treatments in all parameters of biochemical composition of prawn muscles.

Table 5 Proximate composition of prawn meat taken from different treatments (\% on dry weight basis)

\begin{tabular}{lllll}
\hline \multirow{2}{*}{ Parameter } & \multicolumn{4}{l}{ Dietary Treatments } \\
& $\mathbf{T}^{0}($ Control) & $\mathbf{T}^{\mathbf{1}}(\mathbf{6 0} \mathbf{~ m g} / \mathbf{k g})$ & $\mathbf{T}^{2}(\mathbf{1 2 0} \mathbf{~ m g} / \mathbf{k g})$ & $\mathbf{T}^{\mathbf{3}}(\mathbf{1 8 0} / \mathbf{m g} / \mathbf{k g})$ \\
\hline Moisture (\%) & $80.86 \pm 0.56$ & $78.59 \pm 0.42$ & $78.80 \pm 0.49$ & $78.46 \pm 0.54$ \\
Dry matter (\%) & $19.14 \pm 0.65$ & $21.41 \pm 0.52$ & $21.20 \pm 0.48$ & $21.54 \pm 0.44$ \\
Crude protein (\%) & $21.80 \pm 0.24$ & $22.73 \pm 0.18$ & $22.95 \pm 0.27$ & $22.42 \pm 0.16$ \\
Crude fat (\%) & $1.8 \pm 0.11$ & $1.5 \pm 0.19$ & $1.7 \pm 0.20$ & $1.3 \pm 0.15$ \\
Ash (\%) & $5.3 \pm 0.18$ & $4.9 \pm 0.13$ & $5.8 \pm 0.21$ & $5.2 \pm 0.17$ \\
NFE (\%) & $1.3 \pm 0.06$ & $1.6 \pm 0.09$ & $1.5 \pm 0.08$ & $1.4 \pm 0.04$ \\
\hline
\end{tabular}

*Means of three replicates. Moisture and dry matter on wet weight basis.

\section{Discussion}

\section{Effect of marigold oleoresin on water quality}

The quality of water is very important in the culture of crustaceans, since use of feeds is known to have an influence on water quality, there by affecting the species cultured. Maintenance of good water quality is essential for both survival and optimal growth of fish and shellfish. Important water quality parameters such as temperature, $\mathrm{pH}$, dissolved oxygen, free carbon dioxide, total alkalinity and ammonianitrogen were measured weekly throughout the experiment and no adverse effect of diacetate of lutein-mesozeaxanthin on water quality was observed and the recorded values could be considered suitable for optimum growth of $M$. rosenbergiiwhich is similar to results obtained by Ravishankar, ${ }^{32}$. 1,33-35

\section{Effect of diacetate of lutein-mesozeaxanthin on growth of $M$. rosenbergii}

Carotenoids can influence on growth and survival of fish and shellfishes, but the effects of carotenoids on growth and survival rate of aquatic organisms have been controversial, because several studies reporting a positive influence whereas others did not find any effect ${ }^{4,36,37}$ have been reported that the carotenoids could enhance nutrient utilization and might ultimately improve growth, play an important role in the intermediary metabolism of aquatic animals. Pre-juvenile $(0.115 \mathrm{~g})$ white shrimp (L. vannamei) fed dietary supplementation of Hi-Zeaxanthin or Zeaxanthin short chain like diactate during 7 weeks, the average weight and survival rate was significantly higher than control group. ${ }^{5}$. Eduardo Aguirre-Hinojosa et al. ${ }^{9}$ have indicated that juvenile of $L$. vannamei fed diets supplemented with xanthophylls (75\% Zeaxanthin, 15\% lutein) improved survival of shrimps fed treatment diets compared to those fed the control diet but there were no significant differences in growth between experimental groups fed different diets. White shrimp (L. Vannamei) fed with three different treatments (synthetic astaxanthin, lutein and astaxathin derives from marigold extract) have shown higher growth, lower FCR and higher survival on marigold treatments as compared to other treatments and control group. ${ }^{6}$ Survival rate of juvenile $(2.5 \mathrm{~g})$ white shrimp $(L$. Vannamei) fed supplemented diet of Hi-Zeaxanthin for 30 days was significantly higher as compared to the control group. ${ }^{5}$ White shrimp (L. Vannamei) post larvae (PL 17) fed for 11 days with H1-Zeaxanthin had a noticeable improvement in their survival rate. ${ }^{9}$ In present study, diacetate of lutein-mesozeaxanthin as a one of the carotenoids could enhance growth of M. rosenbergii. However Olsen RE et al. ${ }^{8}$ have reported that the Atlantic salmon fed with two xanthophylls carotenoids (astaxanthin and lutein), had no significant effect or growth performance such as FCR, SGR, WG and condition factor. Similarly, ${ }^{38-40}$ found no effect of synthetic and natural carotenoids on growth in salmonids.

\section{Effect of marigold oleoresin on proximate composition of prawn meat}

Carcass composition is known to be influenced by many factors such as age, sex, maturity and feeding conditions. Among these factors, the type and nature of feed ingested are considered to be the most important. ${ }^{41-43}$ In the present study, $M$. rosenbergiifed different levels of diacetate of lutein-mesozeaxanthin did not affect significantly on biochemical composition of prawn muscle. Similar results were also reported by other workers. Eduardo Aguirre-Hinojosa et al. ${ }^{9}$ have noted that supplementation of experimental diets with Tagetes erecta extract (marigold oleoresin) on Litopenaeus vannamei did not significantly alter the proximate composition of the practical diet because very small amounts were required to attain the desired concentrations in the feeds (less than $0.5 \%$ of the total ingredients). The same results were reported by Arredondo-Figueroa et al. ${ }^{10} \&$ Flores et al. ${ }^{11}$ There were no significant differences in proximate composition (crude protein, crude fat, moisture and ash) of rainbow trout with initial weight of $135 \mathrm{~g}$ after 60 days of feeding with supplementation of astaxathin. ${ }^{44}$ Dietary carotenoid sources (1.8\% marigold flowers, $5 \%$ red pepper and $70 \mathrm{mg} \mathrm{kg}-1$ astaxathin) on rainbow trout weighing $120.57 \mathrm{~g}$ for 60 days did not significantly affect fatty acid composition of the fish fillets. ${ }^{45-47}$

\section{Conclusion}

The present study showed that the giant freshwater prawn, $M$. rosenbergiifed a diet containing $60 \mathrm{mg} / \mathrm{kg}, 120 \mathrm{mg} / \mathrm{kg}$ and $180 \mathrm{mg} / \mathrm{kg}$ of diacetate of lutein-mesozeaxanthin for 60 days indicated increased growth of $M$. rosenbergiibut did not affect significantly on biochemical composition of prawn muscle in this species. Further work needs to be carried out for more investigation on effect of diacetate of luteinmesozeaxanthin on growth and proximate composition in other finfish and shellfish.

\section{Acknowledgements}

This research work was supported by Karnataka Veterinary \& Animal and Fisheries Sciences University at College of Fisheries, Mangalore the Ph.D degree programme of 1st author.

\section{Conflicts of interest}

None. 


\section{References}

1. Jayaram KE. M.F.SC. Thesis Submitted to University Agricultural Sciences, Bangalore, India. 1998p.91.

2. Mather PB, De Bruyn M. Genetic diversity in wild stocks of the giant freshwater prawn, Macrobrachium roasenbergii: implications for aquaculture and conservation, NACA, World Fish Centre Quarterly. 2003;26(4):4-7.

3. FAO Aquaculture Production Statistics 1989-1998. FAO Fisheries circular 815 (ev. 12). FAO, Rome, Italy. 2000.

4. Jin N, Lixia T, Heizhao Lin, Yongiian L. Carotenoids in Aquaculture: An Overview. J Anim Sci Biotech. 2011;2(1):44-58.

5. Hinojosa. Method for increasing the health condition of crustaceans in aquaculture. United States Patent Application Publication, USA. 2008.

6. Rohriguez. Enhanced feeding and growth rates of aquatic animals fed an astaxanthin product derived from marigold extract. United States Patent, USA. 2008.

7. Boonyaratpalin $M$, Thongrod S, Supamattaya $K$, et al. Effect of $\beta$ carotene source, Dunaliella salina, and astaxanthin on pigmentation, growth, survival and health of Penaeus monodon. Aquaculture research. 2001;32(suppl):182- 190 .

8. Olsen RE, Baker RTM. lutein does not influence flesh astaxanthin pigmentation in the Atlantic salmon (Salmo salar L.). Aquaculture 2006;258(1-4):558-564.

9. Eduardo AH. Pigmentary and Zootechnical Responses of Juvenile Litopenaeus vannamei (Boone, 1931) Maintained on Diets Supplemented with Xanthophylls of Marigold Tagetes erecta Flowers. The Israeli Journal of Aquaculture. 2012;64:795-803.

10. Arredondo-Figueroa JL, Pedroza-Islas R, Ponce-Palafox JT, et al. Pigmentation of pacific white shrimp (Litopenaeus vannamei, BOONE 1931) with esterified and saponified carotenoids from red chile (Capsicum annuum) in comparison to astaxanthin. Revista Mexicana de Ingeniería Química. 2003;2:101-108.

11. Flores M, Díaz F, Medina R, et al. Physiological, metabolic and haematological responses in white shrimp Litopenaeus vannamei(Boone) juveniles fed diets supplemented with astaxanthin acclimated to lowsalinity. Aquaculture Research. 2007;38(7):740-747.

12. Eonseon J, Polle JW, Lee HK, et al. Xanthophylls in microalgae: from biosynthesis to biotechnological mass production and application. Microbiol Biotechnol. 2003;13(2):165-174.

13. Bernhard K, Broz J, Hengartner U, et al. Pigmentation with carotenoides. US Patent No. 1997;5:548-670.

14. Bletner JK, Mitchell, RP, et al. The effect of Eimeria maxima on broiler pigmentation. Poultry Science. 1966;45(4):689-694.

15. Hencken H. Chemical and physiological behavior of feed carotenoids and their effects on pigmentation. Poultry Science. 1992;71(4):711-717.

16. Levi LW. Trans-xanthophyll ester concentrates of enhanced purity and methods of making same. US Patent No. 2001;6:191-293.

17. IOM. Institute of Medicine. 2000.

18. Bodi Hui. Carotenoid chemistry and biochemistry. Bejing: Chinese light industry publisher. 2005

19. Subczynski WK, Markowska E, Sielewiesiuk J. Effect of polar carotenoid on the oxygen diffusion-concentration product in lipid bilayers. An EPR spin label study. Biochim Biophys Acta. 1991;1068(1):68-72.

20. Sajilata MG, Singhal RS, Kamat MY. The carotenoid pigment zeaxanthinA review. Compreh Rev Food Sci Food Safety. 2008;7(1):29-50.

21. Bone RA, Landrum JT, Tarsis SL. Stereochemistry of the human macular carotenoids. Invest Ophthalmo Vis Sci. 1993;34(6):2033-2040.
22. Bone RA, Landrum JT, Tarsis SL. Preliminary identification of the human macular pigment. Vision Research. 1985;25(11):1531-1535.

23. Handelman GJ, Snodderly DM, Krinsky NI, et al. Biological control of primate macular pigment. Biochemical and densitometric studies. Invest Ophthalmol Vis Sci. 1991;32(2):257-267.

24. Snodderly DM, Handelman GJ, Adler AJ. Distribution of individual macular pigment carotenoids in central retina of macaque and squirrel monkeys. Invest Ophthalmol Vis Sci. 1991;32(2):268-279.

25. Maoka T, Arai A, Shimizu M, et al. The first isolation of entiomeric and meso-zeaxanthin in nature. Comp Biochem Physiol B. 1986;83(1):121124

26. Hardy R. Fish Feed Formulation. In: ADCP (Eds.), Fish Feed Technology. Rome, FAO, ADCP/REP/80/. 1980;11:233-39.

27. APHA. Standard methods for the Examination of water and Wastewater. (18th Edn), American Public Health Association, Washington DC, USA. 1995.

28. Tacon AGJ. Standard methods for the nutrition and feeding of farmed fish and shrimp, Washington DC, Argent Laboratories Press, USA, pp. 454. 1990.

29. De Silva SS, Anderson TA. Fish nutrition in aquaculture. Chapman \& Hall, Press London. 1995;pp.319.

30. AI Q, Mai K, Tan B, et al. Replacement of fish meal by meat and bone meal in diets for large Yellow croaker (Pseudosciaena crocea). Aquaculture. 2006;260(1-4):255-263.

31. Bekcan S, Dogankaya L, Cakirogullari GC. Growth and body composition of European catfish (Silurus glanis L.) fed diets containing different percentages of protein. The Israeli Journal of Aquaculture Bamidgeh. 2006;58: 137-142.

32. Ravishkar AN. Observation on growth response of Macrobrachium rosenbergii fed different pelleted feeds. M.F.SC. Thesis Submitted to University Agricultural Sciences, Bangalore,India. 1983;pp.152.

33. Ramachandra Naik AT, Murthy HS, Rajesh KM, et al. Stabilty in water and sinking rate of pelleted feeds formulated from locally available ingredients. Fshery Technology. 2000;38(2):121-129.

34. Srinivasa Ds. Effect of G-probiotic on growth, body composition and survival of giant freshwater prawn, Macrobrachium rosenbergii (de Man) and Indian major carp, Labeo rohita (Ham), M.F.SC. Thesis Submitted to University Agricultural Sciences, Bangalore, India. 2000;pp.113.

35. Prakash P, Muthy. Effect of feed attractant on growth, survival and fed utilization in freshwater prawn, Macrobrachium rosenbergii (de Man). M.F.SC. Thesis Submitted to University Agricultural Sciences, Bangalore, India. 2004.

36. Niu J, Li CH, Liu YJ, et al. Dietary values of astaxanthin and canthaxanthin in Penaeus monodon in the presence and absence of cholesterol supplementation: effect on growth, nutrient digestibility and tissue carotenoid composition. Br J Nutr. 2011;108(1)6:80-91.

37. Amar EC, Kiron V, Satoh S, et al. Influence of various dietary synthetic carotenoids on bio-defence mechanisms in rainbow trout, Oncorhynchus mykiss(Walbaum). Aquac Res. 2001;32(Suppl I):162-173.

38. Rehulka J. Influence of astaxanthin on growth rate, condition and some blood indices of rainbow trout Oncorhynchus mykiss. Aquaculture. 2000;190(1-2):27-47.

39. Yasemen Y, Buyukchapar H, Yanar M, et al. Effects of carotenoids from red pepper and marigold flower on pigmentation, sensory properties and fatty acid composition of rainbow trout. Food Chemistry. 2007;100(1):326-330.

40. Amar EC, Kiron V, Satoh S, et al. Enhancement of innate immunity in rainbow trout (Oncorhynchus mykiss Walbaum) associated with dietary intake of carotenoids from natural products. Fish Shellfish Immunol. 2004;16(4):527-537. 
41. Parove J. The effect of vitamin supplements to the feed mixture for intensive carp rearing on the chemical composition of the body. Bull Vyzk Osta Ryb Hydrobiol Vodmany. 1976;12(2):15-26.

42. Reimers J, Meske C. The influence of fish meal fry fed on body composition of carp. 1997.

43. Srikar LN, Keshavanath P, Peter M. Changes in biochemical composition of Clarias batrechus (Linn). Befor and after spawning. J Agric Sci. 1979;13(1):87-88.

44. Juanjuan Z. Effect of dietary astaxanthin on pigmentation of flesh and tissue antioxidation of rainbow trout (Oncorhynchus mykiss). Aquacul Int. 2013;21:579-589.
45. Mustafa G, Mahmut Y, Metin K, et al. The Effects of Red Pepper, Marigold Flower, and SyntheticAstaxanthin on Pigmentation, Growth, and Proximate Composition of Penaeus semisulcatus. Turk J Vet An Sci. 2013;30:359-365.

46. http://www.fao.org/fishery/org/GlobalRecord/en.

47. AOAC. Official methods of analysis. (12th edn), Association of Analytical chemists Washington, DC, USA. 1975;pp.1234-1237. 